\title{
The potential processing of rice husk waste as an alternative media for ornamental plants
}

\author{
Andi Muhamad lqbal Akbar Asfar ${ }^{(\mathbb{D}) * 1}$, Andi Muhammad Irfan Taufan \\ Asfar ${ }^{\mathbb{D}}$, Sharma Thaha ${ }^{\mathbb{D}}$ 2, Ady Kurnia ${ }^{\mathbb{D}}$, \& Adji Syaifullah ${ }^{2}$
}

'State Polytechnic of Ujung Pandang, Indonesia

2Muhammadiyah University of Bone, Indonesia

3Indonesia Timur University, Indonesia

*andiifalasfar@gmail.com

\begin{abstract}
The problem of rice husk waste as a result of rice processing is a major problem in Sanrego Village, especially in the Pada Elo' Farmer Group. The accumulation of rice husk waste while the land area to accommodate a lot of rice husk waste during the harvest season forced the farmer groups to burn it. However, another problem that arises is the emergence of air pollution and the results of burning rice husk waste are useless because they are not used properly. Therefore, this community service will process the potential of rice husk waste into husk charcoal by providing information, knowledge, and skills on how to process rice husk waste into rice husk charcoal which can be used as an alternative media for ornamental plants which are currently the prima donna. The implementation method consists of three stages, namely Tudang Sipulung, Mario-rio, and Mappesabbi which are taken from the Bugis tradition of having a philosophy of working together, thus directing farmer groups to participate and be fully involved (participatory by doing). The results obtained by the average partner member experienced an $82,5 \%$ increase in information and knowledge aspects as well as skills and were able to grow their entrepreneurial spirit, especially processing rice husk waste.
\end{abstract}

Absrak Permasalahan akan limbah sekam padi sebagai hasil dari pengolahan beras menjadi permasalahan utama di Desa Sanrego khususnya pada Kelompok Tani Pada Elo'. Menumpuknya limbah sekam padi sementara luas lahan untuk menampung banyak limbah sekam padi ketika musim panen memaksa pihak kelompok tani untuk membakarnya. Namun, permasalahan lain yang muncul adalah munculnya pencemaran udara serta hasil pembakaran limbah sekam padi menjadi sia-sia sebab tidak dimanfaatkan dengan baik. Oleh karena itu, pengabdian kepada masyarakat ini akan melakukan olah potensi limbah sekam padi menjadi arang sekam dengan memberikan informasi, pengetahuan, dan keterampilan mengenai cara pengolahan limbah sekam padi menjadi arang sekam padi yang dapat digunakan sebagai media alternatif tanaman hias yang saat ini menjadi primadona. Metode pelaksanaan yang dilakukan terdiri atas tiga tahapan yaitu Tudang Sipulung, Mario-rio, dan Mappesabbi yang diambil dari tradisi masyarakat Bugis memiliki filosofi dalam bekerjasama, sehingga mengarahkan kelompok tani untuk berpartisipasi dan terlibat secara penuh (participatory by doing). Hasil yang diperoleh rata-rata anggota mitra mengalami penigkatkan $82,5 \%$ dalam aspek informasi dan pengetahuan serta keterampilan serta mampu menumbuhkan jiwa kewirausahaannya khususnya mengolah limbah sekam padi.

Keywords: rice husk waste; husk charcoal; rice mill; rice granary

\section{¿ OPEN ACCESS}

Citation: Asfar. A. M. I. A., A. M. I. T. Asfar, S. Thaha, A. Kurnia, \& A. Syaifullah. (2021). The potential processing of rice husk waste as an alternative media for ornamental plants. Riau Journal of Empowerment, 4(3), 129-138. https://doi.org/10.31258/raje.4.3.129-138

Received: 2021-08-06 Revised: 2021-12-24 Accepted: 2021-12-24

Language: English (en)

Funding: Kementrian Riset Teknologi / Badan Riset Inovasi Nasional Republik Indonesia

ISSN 2623-1549 (online), 2654-4520 (print)

(C) 2021 Andi Muhamad lqbal Akbar Asfar, Andi Muhammad Irfan Taufan Asfar, Sharma Thaha, Ady Kurnia, \& Adji Syaifullah. Author(s) retain the copyright of article published in this journal, with first publication rights granted to Riau Journal of Empowerment. The article is licenced under Creative Commons Attribution 4.0 International License. This license permits unrestricted use, distribution, and reproduction in any medium, provided the original author and source are credited. 


\section{INTRODUCTION}

Ornamental plants are the prima donna today, where almost all circles and various areas are busy collecting certain types of flowers to beautify the yard and even the terrace of the house. The high interest in ornamental plants also causes a high demand for good planting media to support the healthy growth of collected ornamental plants. Various ornamental plants that are currently the prima donna are Aglonema, Sansiviera, Peperomia and various cacti which of course require planting media that have nutrients and are able to bind water. Plant gro wth is strongly influenced by the availability of water and nutrients including the porosity, humidity and aeration of the growing media, such as rice husks (Fahmi, 2019). The importance of the characteristics of a good planting medium is because the availability of nutrients in plants is quite limited, so that a good planting medium has the characteristics of its ability to have aeration and drainage and has a $\mathrm{pH}$ that is in accordance with the plant, including the adequacy of organic matter as a nutrient supplier because the planting medium is one of the factors that affect the growth of plants. determine the good and bad of plant growth ( Hisani \& Herman, 2019). The level of nutrient concentration in the planting media must be right so that plants do not experience a lack or excess of nutrients (Maitimu \& Suryanto, 2018).

Along with the increasing demand for planting media to meet the use of ornamental plants as well as for farming purposes, rice husks have become one of the most wanted planting media. Rice husk is widely used as a planting medium because it can improve soil structure as well as low prices and ease of access (Adiprasetyo et al., 2020). Rice husk is considered waste because it is the end result of the rice processing or rice milling process that is not utilized. Rice husk waste can be processed into planting media through a series of writing processes, namely rice husk waste is burned until it is dark black with an incomplete combustion system or before it becomes ashes. So as to produce rice husk charcoal which has a selling value.

Rice husk charcoal contains high levels of silica, namely $87-97 \%$ which can increase plant resistance to nutrient imbalances, strengthen stems, so that plants do not fall easily and strengthen tissues due to their ability to reduce abiotic and biotic stresses caused by the presence of silica in leaves and helps the process of photosynthesis and translocation of $\mathrm{CO}_{2}$ and $\mathrm{P}$ to panicles (Dharmasika et al., 2019). According to Zahanis and Herman (2019), the content of rice husk charcoal is $\mathrm{SiO}_{2}(52 \%), \mathrm{C}(31 \%), \mathrm{K}(0.3 \%), \mathrm{N}(0.18 \%), \mathrm{P}(0.08 \%)$, and calcium $(0,14 \%)$ and contains other elements such as $\mathrm{Fe}_{2} \mathrm{O}_{3}, \mathrm{~K}_{2} \mathrm{O}, \mathrm{MgO}, \mathrm{CaO}, \mathrm{MnO}$ and $\mathrm{Cu}$ in small amounts where husk charcoal is able to increase potassium levels in the soil. Rice husk charcoal mixed with soil can improve the pores of the planting media, so it is good for root respiration, maintains soil moisture, is able to bind water that can be absorbed by plants and encourages the growth of microorganisms that are useful for soil and plants (Yuliana, Widyawati, \& Sutrisno, 2020).

One of the areas in South Sulawesi, namely Sanrego Village, Bone Regency, was given the nickname of the rice barn area because every year it can harvest up to 2 times and an adequate irrigation system that affects the yield of rice plants in good quantity. However, success in harvesting every year is not followed by success in processing rice husk waste. Rice husk waste in several rice mills is allowed to accumulate. Sometimes some brick-making manufacturers use rice husk waste to be used in brick burning, but it is still not enough to reduce the pile of rice husk waste.

Low optimization of rice husks has resulted in the residents of Sanrego Village who have rice mills to burn piles of rice husk waste. This triggers air pollution which can cause health 
problems. In addition, another way that is usually taken by the owner of the rice mill is to throw it in the river. A process like this, of course, will cause problems in the river water ecosystem which can be polluted and the occurrence of river silting. The lack of counseling and access to information on processing rice husk waste has resulted in the residents of Sanrego Village including partners taking inappropriate ways to reduce the pile of rice husk waste. Therefore, the purpose of implementing this community service is to provide knowledge and skills to the residents of Sanrego Village, especially to the Pada Elo' Farmer Group in optimizing the utilization of rice husk waste through processing potential rice husk waste which can be utilized as a planting medium in farming, such as media planting for ornamental purposes.

\section{METHOD}

The implementation of community service is carried out in stages to achieve the expected goals. The location of the service implementation was in Sanrego Village, Kahu District, Bone Regency, South Sulawesi Province which will be held from 01 May to 30 September 2021. Partner was the Pada Elo' Farmers Group consist of 10 members which has problems processing rice husk waste, which every harvest season becomes a crucial problem because of the need for land to store rice husk waste.

Indicators of success as a form of achievement of community empowerment in the implementation of this service have two main focuses, namely knowledge, and skills. Aspects of knowledge, partners have understood information about the procedures for processing rice husk waste as well as profitable commercial benefits including practical ways to reduce the quantity of rice husk waste. Aspects of skills, partners are able to process rice husk waste into husk charcoal or biochar which can be used as an alternative planting medium that has many benefits for plants. In addition, partners will be able to carry out commercialization activities through the sale of biochar products by first being able to carry out packaging and labeling to produce product visualizations that are more attractive to consumers in addition to the benefits of the husk charcoal products produced. Therefore, this activity has a significant impact on the welfare of the Pada Elo' Farmer Group

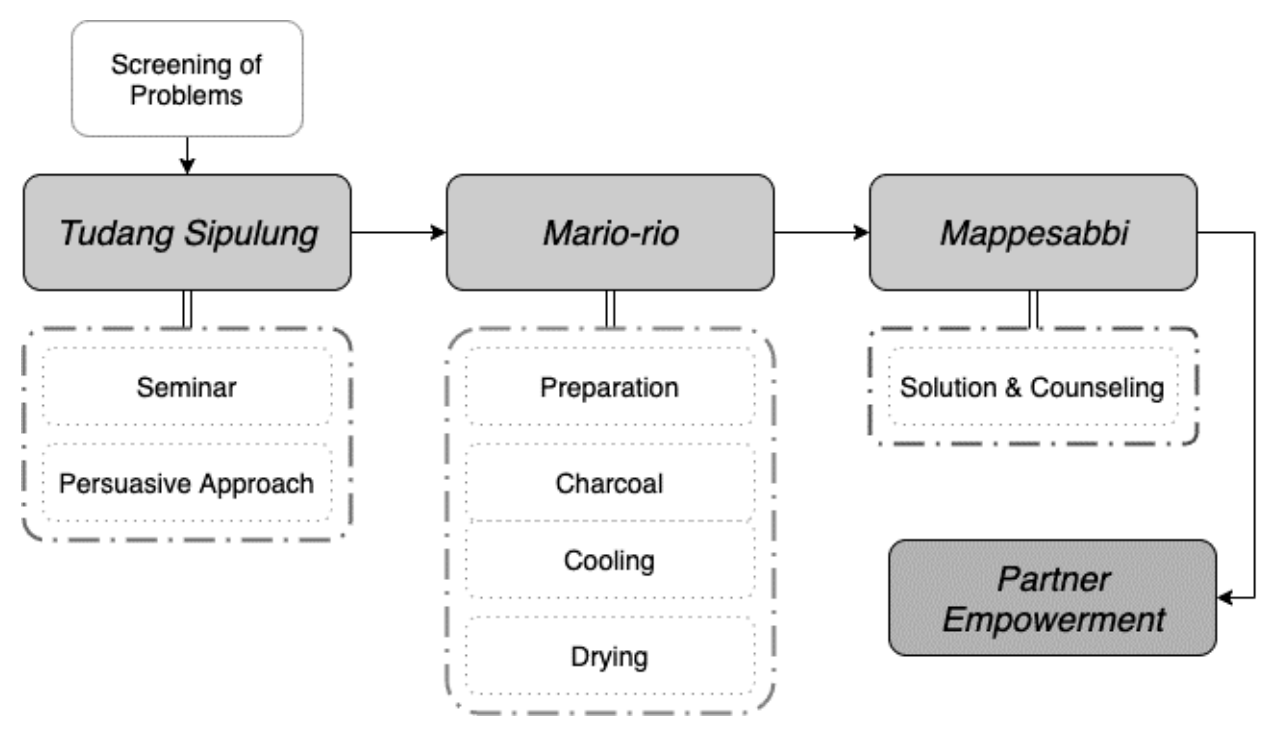

Gambar 1. Method of Potential Processing of Rice Husk Waste 
A description of the stages of implementing community service as follows.

\section{Tudang Sipulung}

Tudang sipulung means sitting together to talk about the activities to be carried out. This activity is to provide an explanation to partners regarding the implementation of community service activities (Yaser, Asfar, Asfar, Rianti \& Budianto, 2020) in processing rice husk waste into husk charcoal which can be used as a planting medium, especially ornamental plants.

2. Mario-rio

Mario-rio is working on an activity with fun, where partners are directly involved in all stages and are enthusiastic to know and increase their skills to process rice husk waste into husk charcoal which has commercial value for sale or personal use (Sumiati, Asfar, Asfar, Aswan, Dahniar \& Hasanuddin, 2021). The implementation of the Mario-rio stages, starting with the preparation of raw materials and tools, writing to drying the obtained husk charcoal.

\section{Mappesabbi}

The Mappesabbi stage is an evaluation carried out to provide two-way communication, where partners reveal the obstacles faced (Asfar, Asfar \& Cheriani, 2020) during processing rice husk waste into husk charcoal and the community service implementation team provides solutions to problems after the implementation of the Mario-rio activity so that partners are truly independent to process the accumulated rice husk waste into products that have economic value such as husk charcoal. To find out the improvement of partner skills, a post-test was carried out by first carrying out a pre-test at the Tudang sipulung stage. The results of the pre-test and post-test will be compared and analyzed using a frequency distribution by testing the mean score of each aspect. There are two aspects that are analyzed in the evaluation stage, namely the knowledge of partners in processing rice husk waste (Knowledge) and the implementation stages of processing rice husk waste (Skill/Process) to assess the skill level of partners after the Mario-rio to Mappesabbi stages.

\section{RESULT AND ACHIEVEMENT}

The implementation of community service, especially the Pada Elo Farmer Group partners in Sanrego Village, gave satisfactory results because the partners enthusiastically participated in all stages in the implementation of this community service. The achievement of the results of the implementation of this service to partners, namely the Pada Elo' Farmer Group, provides a satisfactory improvement in the aspects of partner knowledge and skills. The knowledge aspect has an increase in the percentage of $45-50 \%$, while the knowledge aspect increases significantly with an increase in the range of $55-65 \%$ which can be seen in Table 2 . The potential results of processing rice husk waste into rice husk charcoal are as follows.

\section{Tudang sipulung}

Activities to support the Tudang sipulung stage were first observed to get to know the potential of rice husk waste, including screening for partner problems in processing rice husk waste. Therefore, the results of the screening were formulated by the implementing team regarding systems and processes to streamline the implementation of community service at the Pada Elo' Farmer Group. Screening results can be seen in Table 1. 
Tabel 1. Identification of Problems with Farmer Group Partners Pada Elo'

\begin{tabular}{|c|c|c|}
\hline Problems & Description & Implementation Targets \\
\hline $\begin{array}{ll}\text { Rice } & \text { husk } \\
\text { waste } & \end{array}$ & $\begin{array}{l}\text { There is no treatment of accumulated rice } \\
\text { husk waste and the reduction of rice husk } \\
\text { waste is carried out by burning and } \\
\text { dumping it in the river. The rice mill can } \\
\text { process as much as } 350 \text { tons of rice (an } \\
\text { average of } 3 \text { tons per day for } 3 \text { months) } \\
\text { and } 250 \text { tons into the rice for one product } \\
\text { in one harvest. The by-product of milling } \\
\text { rice into rice produces } 50 \text { tons of bran and } \\
50 \text { tons of husks. In addition, other rice } \\
\text { mills usually process a maximum of } 1-2 \\
\text { tons of rice per day (for } 2-3 \text { months). For } \\
1 \text { ton, the equivalent of } 750 \mathrm{~kg} \text { of dry } \\
\text { unhulled rice is milled into } 570-600 \mathrm{~kg} \text { of } \\
\text { rice. By-products are also in the form of } \\
\text { bran and rice husk waste } 150-180 \mathrm{~kg} \text { per } \\
\text { one production. }\end{array}$ & $\begin{array}{l}\text { Education on potential rice } \\
\text { husk waste through Tudang } \\
\text { Sipulung to reduce piles of } \\
\text { rice husk waste at partner rice } \\
\text { mills. }\end{array}$ \\
\hline Support tools & $\begin{array}{l}\text { There are no tools to support a simple } \\
\text { charcoal process that residents can } \\
\text { replicate, including the Pada Elo' Farmers } \\
\text { Group partners. }\end{array}$ & $\begin{array}{l}\text { Making a simple combustion } \\
\text { cylinder to help the } \\
\text { distribution of charcoal on } \\
\text { the husks and to control the } \\
\text { incomplete combustion } \\
\text { process to produce good } \\
\text { quality rice husk charcoal. }\end{array}$ \\
\hline
\end{tabular}

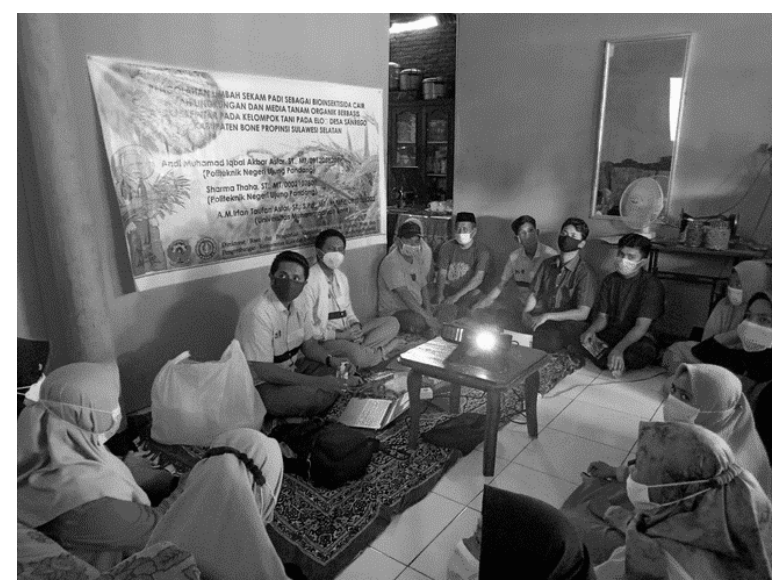

Gambar 1. Tudang Sipulung Implementation by Team and Pada Elo' Farmer Group Partner

The implementation of Tudang sipulung in Figure 1 is carried out by giving short seminars and discussions with partners regarding the implementation of community service activities (Asfar, Widiastini \& Rahman, 2019) as shown in Figure 1. At this stage, partners are given information about the outline of rice husk waste processing become husk charcoal and also 
information on the benefits of husk charcoal for plants, especially in its application to ornamental plants which are mostly owned by wives and partner members themselves.

Tudang sipulung has an impact on the training, the closeness between partners and the community service implementation team (Asfar, Yaser, Istiyana, Asfar \& Kurnia, 2021), so partners are enthusiastic to participate and are in the process of adding skills to diversify rice husk skills into rice husk charcoal.

\section{Mario-rio}

The core stages are the core of the implementation of community service activities to the partners of the Pada Elo' Farmer Group through processing the potential of rice husk waste into husk charcoal. At this stage, partners are expected to be fully involved in every Mario-rio process (participatory by doing) (Asfar, Rifai, Ilham, Damayanti \& Asfar, 2021).

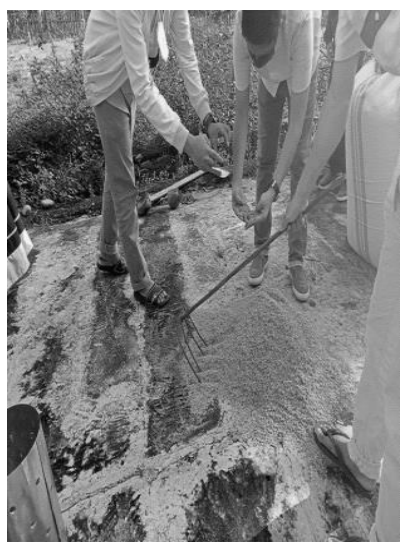

(a)

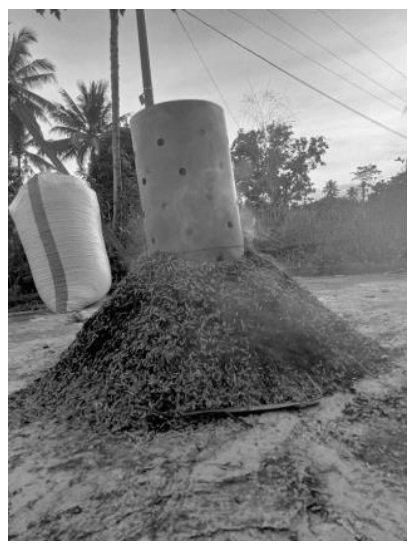

(b)

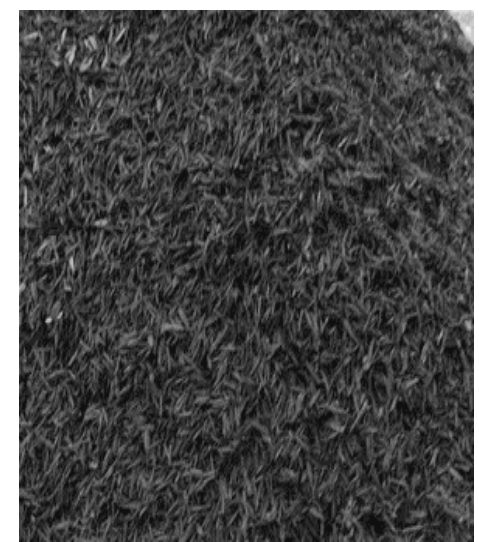

(c)

Gambar 2. The stage of Mario-rio (a) Preparation (b) Rice Husk Charcoal (c) Drying

The process of implementing the Mario-rio stage begins can be described as follows:

a. Preparation of raw materials and equipment

Raw material preparation is done by selecting the raw material for the rice husk. In Figure 2(a), the selected rice husk is dry rice husk waste. Dry rice husks will facilitate the charcoal process. Related equipment prepared is a combustion cylinder, a shovel, and a lighter. Especially for the combustion process, coconut husk and coconut shell or wood are needed to be used as fuel in the process of composing rice husks.

\section{b. Charcoal}

The process of charcoal is done by first preparing coconut husk, coconut shell or wood to be burned in the middle of the combustion cylinder. After the embers are created, the rice husk waste is burned by piling it around the cylinder, so that it resembles a pile of rice husks with a cylinder in the middle. The embers must be maintained to ensure the writing process takes place properly. A good writing process shows that the rice husk charcoal, which was originally yellow, turns into charcoal at several points as shown in Figure 2(b). After the charcoal is formed in the pile of husks, the pile of rice husks is stirred to even out the distribution of heat from the combustion cylinder so that the overall combustion occurs in the pile of rice husks. This process will take \pm 45 minutes for $10 \mathrm{~kg}$ of rice husk waste.

After all the rice husks turn black (charcoal), then the next step is watering. The watering process is carried out until the smoke is no longer visible from the wet husk charcoal. The watering process must be ensured evenly so that changes in rice husk charcoal do not continue 
in the ashing process (ash formation) because heat is still created even though the husk charcoal has been doused with water. Therefore, good husk charcoal is husk charcoal that is burned imperfectly without undergoing the ashing process. This ashing can occur even though the husk charcoal is wet.

c. Drying

Drying is carried out for $\pm 1-2$ days depending on the intensity of sunlight and air humidity. Dry rice husks will look like husks of charcoal separated from one another as shown in Figure 2(c).

\section{Mappesabbi}

The problems faced by partners are given solutions at the Mappesabbi stage. Constraints faced by partners in the packaging system for rice husk charcoal. Therefore, in Figure 3 as the Mappesabbi stage, assistance is provided on how to carry out packaging including labeling rice husk charcoal products. In this Mappesabbi stage, an evaluation of the knowledge and skills of partners is also carried out by giving a post-test to be compared with the results of the pre-test at the Tudang Sipulung stage after all stages have been carried out.

The results of the evaluation of increasing partner knowledge and increasing partner skills as an indicator of the achievement of activity results in processing potential rice husk waste into husk charcoal can be seen in Table 2 .

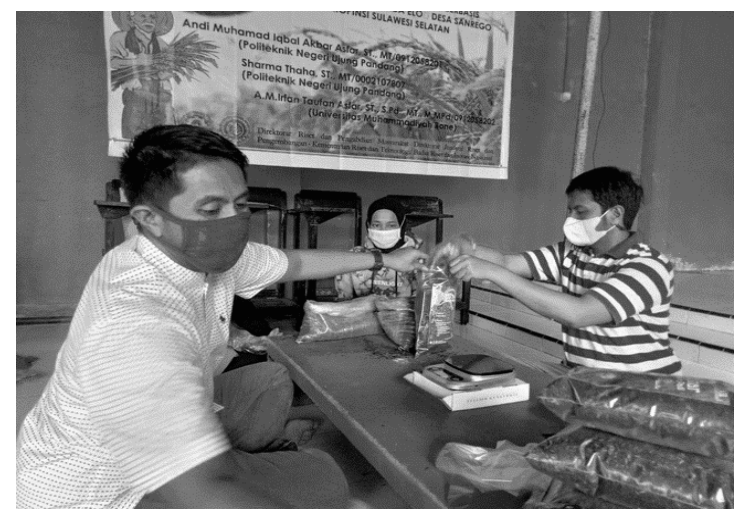

Gambar 3. Implementation Team and The Pada Elo' Farmer Group Partner at the Mappesabbi Stage

The results of the pre-test and post-test analysis in Table 2 were obtained from 5 partner members of the Pada Elo' Farmer Group who attended training on processing potential rice husk waste into husk charcoal and filled out a questionnaire regarding the processing of rice husk waste before and after the implementation was carried out. Using the average (mean) scoring obtained for the knowledge aspect, namely information on processing rice husk waste (K1) with an average pre-test score of 1.6 or $40 \%$ while the post-test 3.4 or $85 \%$. This shows that partners have understood information about the transformation of rice husk waste into various products that are useful for the community, especially in exploring village potentials, such as making briquettes, husk charcoal, and liquid smoke.

The benefits of rice husk waste (K2) have an average pre-test score of 1 or $25 \%$ while the post-test is $75 \%$. From the increase in gain (difference) obtained a gain of $50 \%$ which indicates that partners know that husk charcoal has the composition needed by plants and benefits for plant growth such as Nitrogen $(\mathrm{N})$, Phosphate $(\mathrm{P})$, and Potassium (K). 
In the skill aspect (process) for the stages of the rice husk waste treatment process (S1), the average pre-test score is 1 or $25 \%$, while the post-test is 3.6 or $90 \%$. The result of an increase with a difference or gain of 50\% means a significant increase in understanding and increasing the skills of partners in processing the potential of rice husk waste into husk charcoal. Skilled partners carry out step by step starting from the preparation of raw materials, the charcoal process, and drying.

Tabel 2. Achievement of Results of Potential Rice Husk Waste Processing into Husk Charcoal

\begin{tabular}{|c|c|c|c|}
\hline Aspect & Before & After & $\begin{array}{c}\text { The Percentage of } \\
\text { Gain }\end{array}$ \\
\hline \multicolumn{4}{|l|}{ Knowledge } \\
\hline $\begin{array}{l}\text { Rice husk waste } \\
\text { treatment } \\
\text { information } \\
(\mathrm{K} 1)\end{array}$ & $\begin{array}{l}\text { There is no education } \\
\text { regarding the } \\
\text { processing of rice husk } \\
\text { waste. Usually partners } \\
\text { process it to make it as } \\
\text { rubbing ash. }(40 \%)\end{array}$ & $\begin{array}{l}\text { Partners know the } \\
\text { application of rice } \\
\text { husk waste if it is } \\
\text { processed such as } \\
\text { husk charcoal, } \\
\text { briquettes, and } \\
\text { liquid smoke. } \\
(85 \%)\end{array}$ & $45 \%$ \\
\hline $\begin{array}{l}\text { Benefits of rice } \\
\text { husk waste } \\
\text { (K2) }\end{array}$ & $\begin{array}{l}\text { There is no } \\
\text { information about the } \\
\text { benefits of rice husk } \\
\text { waste to be applied to } \\
\text { plants } \\
(25 \%)\end{array}$ & $\begin{array}{l}\text { Partners have } \\
\text { information and } \\
\text { knowledge about the } \\
\text { composition of } \\
\text { nutrients needed by } \\
\text { plants, especially the } \\
\text { content of N, P, K, } \\
\text { and Silica } \\
(75 \%)\end{array}$ & $50 \%$ \\
\hline \multicolumn{4}{|l|}{ Skill (Process) } \\
\hline $\begin{array}{l}\text { Stages of } \\
\text { processing rice } \\
\text { husk waste } \\
\text { (S1) }\end{array}$ & $\begin{array}{l}\text { There is no skill in } \\
\text { processing rice husk } \\
\text { waste, especially in } \\
\text { making husk charcoal } \\
(25 \%)\end{array}$ & $\begin{array}{l}\text { Having skills in } \\
\text { processing rice husk } \\
\text { waste into husk } \\
\text { charcoal from the } \\
\text { process of preparing } \\
\text { raw materials, } \\
\text { composting } \\
\text { (charcoal), and } \\
\text { drying } \\
(90 \%)\end{array}$ & $65 \%$ \\
\hline $\begin{array}{l}\text { Product } \\
\text { packaging and } \\
\text { labeling } \\
\text { (S2) }\end{array}$ & $\begin{array}{l}\text { No skill } \\
(25 \%)\end{array}$ & $\begin{array}{l}\text { Partners are able to } \\
\text { do product } \\
\text { packaging and } \\
\text { labeling } \\
(80 \%) \\
\end{array}$ & $55 \%$ \\
\hline
\end{tabular}




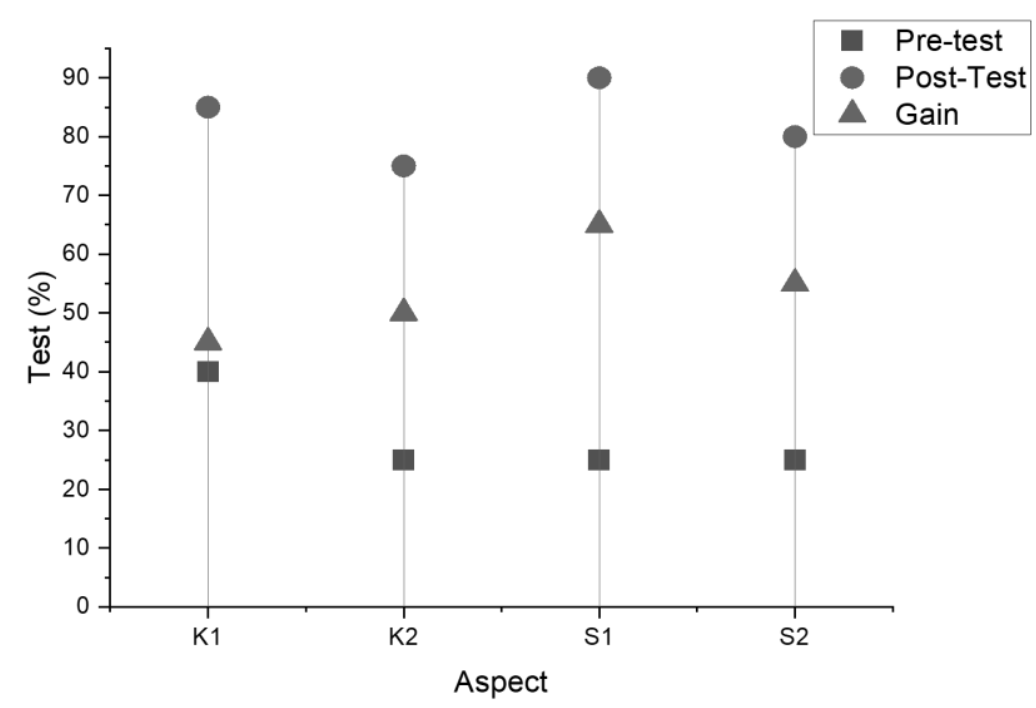

Gambar 3. Results of Increasing the Percentage of Partner Gain in the Implementation of Potential Rice Husk Waste.

The skill in product packaging and labeling (S2) has an average pre-test score of 1 or $25 \%$ while the post-test is 3.2 or $80 \%$. Increased partner skills can be seen in the partner's ability to package and label products. This packaging and labeling are also carried out by training partners on how to weigh the product for each package of husk charcoal. The result of the increase before and after the addition of skills is $55 \%$ which indicates that partners experience a significant increase in skills.

Based on the results of the analysis regarding the increase in the knowledge and skills of partners, an average gain of $55 \%$ or an average increase after processing the potential of rice husk waste into husk charcoal is $82.5 \%$.

\section{CONCLUSION}

Processing the potential of rice husk waste into rice husk charcoal is able to reduce the crucial problems of the Pada Elo Farmer Group partners through the implementation of community service in Sanrego Village, Bone Regency, South Sulawesi. Partners already have the knowledge and skills in transforming rice husk waste into husk charcoal to be applied to plants, especially ornamental plants. In addition, partners have been able to carry out packaging and labeling which are oriented towards commercialization of results to be expected to increase the income of the Pada Elo' Farmer Group members through the production of husk charcoal.

\section{ACKNOWLEDGEMENT}

The team would like to thanks for Research and Technology-BRIN (Ristek-BRIN) which has provided funding for the implementation of the Community Partnership Program for the funding year 2021, the Polytechnic State of Ujung Pandang and the Muhammadiyah University of Bone. 


\section{References}

1. Adiprasetyo, T., Hermawan, B., Herman, W., \& Arifin, Z. (2020). Pelatihan Pembuatan Media Tanam dengan Memanfaatkan Sumber Daya Lokal di Kelurahan Beringin Raya Kota Bengkulu. Jurnal Pengabdian Kepada Masyarakat Dewantara, 3(10), 37-40. Available at https://ojs.unitas-pdg.ac.id/index.php/jpmd/article/view/510

2. Asfar, A.M.I.A., Rifai, A., Ilham, I., Damayanti, D.J., \& Asfar, A.M.I.T. (2021). Pengolahan Ikan Teri Kering Menjadi Abon Asin Gammi. DINAMISIA: Jurnal Pengabdian Kepada Masyarakat, 5(1), 176-180. DOI: https://doi.org/10.31849/dinamisia.v5i1.4488

3. Asfar, A.M.I.A., Yasser, M., Istiyana, A.N., Asfar, A.M.I.T., \& Kurnia, A. (2021). Transformasi Produk Sekunder Pengolahan Minyak Parede Sebagai Produk Sambel Kerak Minyak. DINAMISIA: Jurnal Pengabdian Kepada Masyarakat, 5(2), 384-391. DOI: https://doi.org/10.31849/dinamisia.v5i2.5267

4. Asfar, A.M.I.T., Asfar, A.M.IA., \& Cheriani. (2020). Pelatihan Modifikasi Model Pembelajaran Bagi Guru SD Se-Kecamatan Kahu. Jurnal Dedikasi, 22(1), 25-29. DOI: https://doi.org/10.26858/dedikasi.v22i1.13816

5. Asfar, A.M.I.T., Widiastini, A., \& Rahman, A. (2019). Pengolahan Kayu Sepang (Caesalpinia sappan L.) di Desa Biru Kecamatan Kahu Kabupaten Bone Sulawesi Selatan. Panrita AbdiJunral Pengabdian Kepada Masyarakat, 3(2), 97-104. DOI: https://doi.org/10.20956/pa.v3i2.5379

6. Dharmasika, I., Budiyanto, S., \& Kusmiyati, F. (2019). Pengaruh Dosis Arang Sekam Padi Dan Pupuk Kandang Sapi Terhadap Pertumbuhan Dan Produksi Tanaman Jagung Hibrida (Zea mays L.) Pada Salinitas Tanah. Jurnal Litbang Provinsi Jawa Tengah, 17(2), 195-205. DOI: https://doi.org/10.36762/jurnaljateng.v17i2.799

7. Fahmi, R. (2019). Pengaruh Media Tanam Terhadap Pertumbuhan Stek Mawar Pagar (Rosa multiflora). AGROSAMUDRA: Jurnal Penelitian, 6(1), 74-81. DOI: https://doi.org/10.33059/jupas.v6i1.1509

8. Hisani, W., \& Herman. (2019). Pemanfaatan Pupuk Organik dan Arang Sekam Dalam Meningkatkan Pertumbuhan dan Produksi Tanaman Terong (Selanum Melogena L.). Perbal: Jurnal Pertanian Berkelanjutan, 7(2), 147-155. DOI: http://dx.doi.org/10.30605/perbal.v7i2.1378

9. Maitimu, D. K., \& Suryanto, A. (2018). Pengaruh Media Tanaman dan Konsentrasi AB-Mix Pada Tanaman Kubis Bunga (Brassica oleraceae var bortrytis L.) Sistem Hidroponik Substrat. Jurnal Produksi Tanaman, 6(4), 516-523. Available at http://protan.studentjournal.ub.ac.id/index.php/protan/article/view/674

10. Sumiati, Asfar, A.M.I.T., Asfar, A.M.I.A., Aswan, A., Dahniar., \& Hasanuddin, D. (2021). Habis Manis Sepah Jadi Uang: Pemanfaatan Ampas Tebu Menjadi Boneka Arang Aktif. DINAMISIA: Jurnal Pengabdian Kepada Masyarakat. 5(2), 400-407. DOI: https://doi.org/10.31849/dinamisia.v5i2.5376

11. Yasser, M., Asfar, A. M. I. A., Asfar, A. M. I. T., Rianti, M., \& Budianto, E. (2020). Pengembangan Produk Olahan Gula Merah Tebu dengan Pemanfaatan Ekstrak Herbal di Desa Latellang Kabupaten Bone. Panrita Abdi-Jurnal Pengabdian pada Masyarakat, 4(1), 42-51. DOI: https://doi.org/10.20956/pa.v4i1.7083

12. Yasser, M., Asfar, A.M.I.A., Rianti, M., Asfar, A.M.I.T., \& Budianto. E. (2020). Gula Cair dan Recengan Berbahan Dasar Gula Merah Tebu. Jurnal Dedikasi, 22(1), 69-72. DOI: https://doi.org/10.26858/dedikasi.v22i1.13825

13. Yuliana, E., Widyawati, N., \& Sutrisno, A.J. (2020). Pengaruh Komposisi Media Tanam Terhadap Pertumbuhan dan Hasil Tanaman Bunga Gladiol (Gladiolus Hybridus L.) Flower Plants. Jurnal Teknik Pertanian Lampung, 9(4), 353-360. DOI: http://dx.doi.org/10.23960/jtep1.v9i4.353-360

14. Zahanis., \& Herman, W. (2019). Pengaruh Dosis Arang Sekam Padi Terhadap Pertumbuhan dan Hasil Varietas Cabai Rawit (Capsicum Frutescens L.) Pada Ultisol. Jurnal Embrio, 11(1), 11-23. Available at http://ojs.unitas-pdg.ac.id/index.php/embrio/article/view/425 